\title{
Elementy niekonwencjonalnej polityki pieniężnej Europejskiego Banku Centralnego ${ }^{1}$
}

\begin{abstract}
Andrzej Raczko*
Niekonwencjonalność polityki pieniężnej może być rozpatrywana $w$ zależności od systemu, w jakim jest ona prowadzona. Mówienie o niekonwencjonalności polityki pieniężnej ma sens w odniesieniu do systemów, które uznaja stabilność cen za priorytet, a czynniki kształtujące popyt na pieniadz za instrumenty tej polityki. W niniejszym artykule: po pierwsze, wyodrębniono zbiór wspólnych elementów polityki pieniężnej stosowanych w różnych krajach, które można uznać za czynniki wyznaczające jej konwencjonalność. Po drugie, została dokonana analiza elementów, które wprowadzaja cechy niekonwencjonalności. Po trzecie, pokazane sa skutki różnych form niekonwencjonalności polityki pieniężnej w odniesieniu do jej efektywności oraz możliwości powrotu do polityki konwencjonalnej. Ostatnia część poświęcona jest skutkom wyboru określonej formy niekonwencjonalności przez EBC.
\end{abstract}

Słowa kluczowe: Europejski Bank Centralny, niekonwencjonalna polityka pieniężna.

Nadesłany: 10.04.17 | Zaakceptowany do druku: 28.12.17

\section{Elements of unconventional monetary policy at the European Central Bank}

The unconventionality of monetary policy can be considered depending on the system in which it is functioning.

Talking about unconventionality monetary policy makes sense for systems that recognize price stability, priority, and factors shaping demand for money for instruments of this policy. In this article: firstely a set of common elements of monetary policy applied in different countries was distinguished, which can be considered as factors that determined its conventionality. Secondely, the elements responsible for the introduction the unconventionality are analyzed. Thirdly, the effects of the different forms of political unconventionality in relation to its effectiveness and the possibility of returning to politics conventional is analyzed. The last part is devoted the results of choosing a particular form unconventionality by the ECB.

Keywords: European Central Bank, unconventional monetary policy, monetary policy.

Submitted: 10.04.17 | Accepted: 28.12.17

JEL: E52

\section{Wprowadzenie}

Niekonwencjonalność polityki pieniężnej może być rozpatrywana w zależności od systemu, w jakim jest ona prowadzona ${ }^{2}$. W przypadku, gdy celem polityki pieniężnej jest poziom kursu walutowego, to pole jej oddziaływania jest istotnie ograniczone.

Andrzej Raczko, dr - Narodowy Bank Polski. 
W sytuacji pełnego sztywnego kursu walutowego i swobodnego przepływu kapitału wyeliminowana jest autonomiczna polityka stóp procentowych (por. Blinder, 2001). W systemach bardziej złożonych, dopuszczających wahania kursu walutowego w zdefiniowanym korytarzu oraz w mechanizmie dopuszczającym systematyczną deprecjację, przestrzeń dla polityki kształtującej krajowe stopy procentowe istnieje i ma szczególne znaczenie, gdy połączona jest $\mathrm{z}$ restrykcjami dotyczącymi przepływu kapitału $^{3}$. W opisanych systemach trudno jest mówić o niekonwencjonalnej polityce pieniężnej, ponieważ albo nie ma ona swobody działania (w pełni sztywny kurs walutowy), albo ma charakter eklektyczny, to znaczy posługuje się wieloma instrumentami ,szytymi na miarę", w zależności od sytuacji w danym kraju. Powyższe uwagi wskazują na to, że mówienie o niekonwencjonalności polityki pieniężnej ma sens w odniesieniu do systemów, które uznają stabilność cen za priorytet, a czynniki kształtujące popyt na pieniądz za instrumenty tej polityki.

W niniejszym artykule: po pierwsze, wyodrębniono zbiór wspólnych elementów polityki pieniężnej stosowanych w różnych krajach, które można uznać za czynniki wyznaczające jej konwencjonalność. Po drugie, dokonana jest analiza elementów, które wprowadzają cechy niekonwencjonalności. Po trzecie, pokazane są skutki różnych form niekonwencjonalności polityki pieniężnej w odniesieniu do jej efektywności oraz możliwości powrotu do polityki konwencjonalnej. Po czwarte, na przykładzie Europejskiego Banku Centralnego (EBC), pokazane jest, jak uwarunkowania, wywołane przez kryzys finansowy, popychały do wyboru określonej formy niekonwencjonalności polityki pieniężnej i jakie pełniła ona funkcje. Ostatnia część poświęcona jest skutkom wyboru określonej formy niekonwencjonalności przez EBC.

\section{Elementy konwencjonalnej polityki pieniężnej w świetle strategii bezpośredniego celu inflacyjnego}

W świetle powyższych uwag o niekonwencjonalności polityki pieniężnej należy mówić w odniesieniu do modelu strategii, który ukształtował się w latach 80 . poprzedniego stulecia. Model ten zakłada kilka warunków, które odnoszą się do wspólnych cech polityki pieniężnej stosowanej w różnych krajach. Warunki te wyznacza model definiowany powszechnie, jako strategia bezpośredniego celu inflacyjnego. Kluczowym warunkiem jest istnienie niezależnego banku centralnego, którego celem jest stabilność cen, a głównym instrumentem polityki pieniężnej - krótkoterminowa stopa procentowa.

Spełnienie podstawowych warunków wymaga, aby stabilność cen była zobiektywizowana w postaci określonego miernika inflacji. Za pomocą wybranego miernika inflacji zostaje zdefiniowany poziom celu inflacyjnego. Cel inflacyjny może mieć charakter punktowy albo przedziałowy. Istotą celu inflacyjnego jest to, że konkretyzuje on pojęcie stabilności cen jako dopuszczalnych zmian inflacyjnych, które nie mają negatywnego wpływu na gospodarkę. Równocześnie cel inflacyjny stanowi „busolę” dla podmiotów gospodarczych i ,zobowiązanie” banku centralnego. „Busolę”, ponieważ prowadząc rachunek ekonomiczny, podmioty mogą zakładać inflację równą celowi, „zobowiązane”, ponieważ bank centralny zamierza swoimi działaniami sprowadzać inflację do poziomu zgodnego z celem inflacyjnym ${ }^{4}$. Inflacja może odbiegać od celu inflacyjnego ze względu na oddziaływanie szoków, które mniej lub bardziej odchylają dynamikę cen od przyjętego celu.

Czynnikiem różnicującym strategię bezpośredniego celu inflacyjnego dla poszczególnych krajów jest horyzont, w jakim bank centralny powinien sprowadzić inflację do celu $^{5}$. Element ten nie jest jednoznacznie określany, ponieważ czas niezbędny do sprowadzenia inflacji do celu zależy od siły szoku oraz dopuszczalnych kosztów związanych z szybkością zniwelowania odchylenia inflacji od celu. Ten ostatni czynnik zależy od władz monetarnych poszczególnych krajów i wymaga znalezienia kompromisu pomiędzy wiarygodnością polityki banku centralnego w sensie zdolności do sprowadzania inflacji do celu a skutkami ekonomicznymi nadmiernie luźnej albo restrykcyjnej polityki pieniężnej (por. Tobin, 1983). W przypadku restrykcyjnej polityki pieniężnej koszty związane są z gwałtownym zahamowaniem wzrostu gospodarczego i spadkiem zatrudnienia. W sytuacji luźnej polityki pieniężnej koszty związane są z ryzykiem destabilizacji sektora finansowego. Utrzymywanie zbyt niskiego poziomu stóp procentowych poddaje pre- 
sji marże banków, zachęcając je do prowadzenia ryzykownej polityki kredytowej. W następnej części artykułu zostanie bliżej zanalizowana kwestia, czy i kiedy stopień wrażliwości poszczególnych władz monetarnych na koszty polityki antyinflacyjnej można uznać za przejaw dopuszczenia do niekonwencjonalnej polityki.

Krótkoterminowa stopa procentowa uznawana jest w omawianym modelu polityki pieniężnej za wystarczający jej instrument. Przyjmuje się, że zmieniając krótkookresową stopę procentową, dokonuje się odpowiedniej zmiany całego spektrum stóp procentowych. Obrazowo mówiąc: przy przesunięciu „krótkiego końca” krzywej rentowności następuje równoległe przesunięcie całej krzywej6. Efekt ten jest możliwy ze względu na powiązania rynku finansowego. Zmiana krótkoterminowej stopy procentowej musi spowodować dostosowanie we wszystkich segmentach rynku finansowego, ponieważ na zintegrowanym rynku finansowym nie może występować efekt arbitrażu.

Powyższe uwagi prowadzą do hipotezy, że niekonwencjonalność polityki pieniężnej można rozumieć jako odejście od koncepcji celu inflacyjnego ${ }^{7}$ albo jako posługiwanie się spektrum instrumentów zamiast jednym instrumentem w postaci krótkoterminowej stopy procentowej.

\section{Niekonwencjonalność polityki pieniężnej w sensie odejścia od bezpośredniego celu inflacyjnego}

Przypadek odejścia od koncepcji celu inflacyjnego jest dość złożony, należy bowiem odpowiedzieć na pytanie, czy wpisanie $\mathrm{w}$ mandat innych celów, obok celu stabilności cen, oznacza niekonwencjonalną politykę pieniężną (por. Jensen, 2002)? Problem nie jest łatwy do rozstrzygnięcia, ponieważ należy ocenić, czy stabilność cen może koegzystować w symbiozie $\mathrm{z}$ dodatkowymi celami polityki banku centralnego. Jeśli weźmiemy pod uwagę na przykład mandat Narodowego Banku Polskiego, widzimy, że wyraźnie precyzuje on prymat stabilności cen nad celem dodatkowym. Bardziej skomplikowana jest sytuacja w przypadku amerykańskiego Fed-u, który formalnie zatrudnienie uznaje za równorzędny do stabilności cen cel8.

Ocena systemu w tym przypadku jest bardziej złożona, ale niekoniecznie musi stanowić naruszenie istoty konwencjonalnej polityki pieniężnej, zależy bowiem od tego, jak dodatkowe cele są rozumiane. Dopuszczenie elastyczności $\mathrm{w}$ prowadzeniu polityki pieniężnej, w sensie brania pod uwage kosztów dostosowania stóp procentowych, jest w tym przypadku kluczowe. Najkrótsza ścieżka dostosowania stóp procentowych i sprowadzenia inflacji do celu może być tak zaprojektowana, aby koszt tej operacji $\mathrm{z}$ punktu widzenia strat $\mathrm{w}$ odniesieniu do rynku pracy nie przekraczał pewnej normy. Powyższy mechanizm można zapisać za pomocą następujących warunków:

1) $\mathrm{T}--->\min$,

2) $\mathrm{p}_{\mathrm{T}}=\mathrm{p}^{*}$

3) $\mathrm{U}_{\mathrm{t}}\left(\mathrm{p}_{\mathrm{t}}\right)<\mathrm{U}_{\mathrm{t}}^{*}$, dla $\mathrm{t}=1,2, \ldots \mathrm{T}$,

gdzie: T optymalizowany okres osiagnięcia celu inflacyjnego $\mathrm{p}^{*}, \mathrm{p}_{1}, \mathrm{p}_{2}, \ldots \mathrm{p}_{\mathrm{T}}$ ciąg wskaźników inflacji (ścieżka inflacji) odpowiadających polityce pieniężnej, $\mathrm{U}_{\mathrm{t}}\left(\mathrm{p}_{\mathrm{t}}\right)$ wskaźnik bezrobocia odpowiadajaccy wskaźnikowi inflacji $\mathrm{w}$ danym okresie $\mathrm{t}, \mathrm{U}_{\mathrm{t}}{ }^{*}$ dopuszczalny poziom bezrobocia w okresie t. Sprowadzenie inflacji do celu nie ma być dokonane najszybciej, ale w optymalnym okresie biorącym pod uwage dodatkowe ograniczenia. Jeśli w taki sposób rozumiane jest dochodzenie do celu inflacyjnego, to polityka Fed może być traktowana jako konwencjonalna, mimo istnienia pomocniczego celu. Opisany model stosował amerykański Fed, uzależniając zmiany parametrów polityki pieniężnej od zmian poziomu bezrobocia. Na przykład zastosowana polityka forward guidance kotwiczyła oczekiwania zmian stóp procentowych od z góry zdefiniowanych parametrów rynku pracy ${ }^{9}$.

Niekonwencjonalna polityka pieniężna w odniesieniu do celu miałaby miejsce, gdyby bank centralny na równi z celem inflacyjnym stawiał inny cel, na przykład dynamikę produktu krajowego brutto ${ }^{10}$. $\mathrm{W}$ takim przypadku politykę pieniężną można zapisać w formie:

4) $\sum_{t=1}^{T} Z\left(y_{t}\left(p_{t}\right)-y^{*}, p_{t}-p^{*}\right) \rightarrow \min$

gdzie: funkcja strat społecznej użyteczności $\mathrm{Z}$ ma dwa argumenty, odchylenie dynamiki produktu krajowego brutto i inflacji od przyjętych celów y* i p*. Zadaniem polityki pieniężnej jest ustalenie w średnim okresie 
$\mathrm{T}$ instrumentów polityki pieniężnej w taki sposób, aby minimalizowały straty wynikające $\mathrm{z}$ odchylenia od dwóch realizowanych celów.

Biorąc pod uwagę trudności w odpowiednim zdefiniowaniu funkcji strat, zaproponowano prostszą wersję modelu w postaci nominalnej dynamiki produktu krajowego brutto $\mathrm{Y}_{\mathrm{t}}$ :

5) $\sum_{t=1}^{T}\left[Y_{t}-Y^{*}\right] \rightarrow \min$

Przy uwzględnieniu, że dynamika produktu krajowego brutto jest sumą realnego wzrostu produktu $\mathrm{y}_{\mathrm{t}} \mathrm{i}$ inflacji (dokładniej deflatora cen) $\mathrm{p}_{\mathrm{t}}$, formuła 4 przyjmuje postać:

6) $\sum_{t=1}^{T}\left[y_{t}\left(p_{t}\right)+p_{t}-Y^{*}\right] \rightarrow \min$

Elastyczność polityki pieniężnej polega w tym przypadku na dopuszczalności różnych wariantów tak samo ocenianych w odniesieniu do przyjętego celu. Można uzyskać to samo odchylenie od celu przy niskiej inflacji i wysokim realnie wzroście produktu krajowego, albo odwrotnie: akceptując wysoką inflację i niski wzrost produktu realnego ${ }^{11}$. Jak widać, nowy cel polityki pieniężnej wyraźnie sprzyja środowisku deflacyjnemu. W takim przypadku przestrzeń do prowadzenia ekspansywnej polityki pieniężnej zostaje wyraźnie zwiększona. Dopuszcza ona możliwość utrzymania niskich stóp procentowych nawet w przypadku gwałtownego wyjścia z deflacji (spowodowanej na przykład zewnętrznym szokiem cenowym), jeśli realne tempo wzrostu produktu krajowego brutto jest niskie. Porzucenie luźnej polityki pieniężnej następuje z opóźnieniem, to znaczy dopiero wtedy, gdy pojawiają się wyraźne efekty odbicia aktywności gospodarczej, widoczne $\mathrm{w}$ postaci przyspieszenia tempa wzrostu produktu krajowego.

Oczywiście tak zdefiniowany cel polityki pieniężnej prowadzi do utrzymania nadmiernie zaostrzonej polityki pieniężnej w warunkach stagflacji. W takim przypadku nawet znaczny spadek inflacji, ale wciąż wysoki jej poziom nie musi prowadzić do poluzowania polityki pieniężnej i wsparcia wątłego, realnego wzrostu gospodarczego. Dopiero istotna redukcja poziomu inflacji i tym samym silny impuls do zmiany oczekiwań inflacyjnych otwiera przestrzeń do złagodzenia polityki pieniężnej.
Odejście od konwencjonalnej polityki pieniężnej w formie porzucenia celu inflacyjnego i przyjęcie nominalnego poziomu produktu krajowego brutto jest istotną jakościową zmianą. Przeprowadzona analiza wskazuje, że nowy cel może się sprawdzać w nietypowych sytuacjach, przedłużając luźną politykę pieniężną w okresie niskiej aktywności gospodarczej, kiedy następuje stopniowa odbudowa potencjału produkcyjnego $^{12}$.

Niestety rezygnacja z celu inflacyjnego może powodować trwałe odkotwiczenie oczekiwań inflacyjnych. Podmioty gospodarcze traca ,busolę” w postaci wskaźnika inflacji. Różne „mieszanki” inflacji i realnego wzrostu produktu krajowego brutto zawarte w celu zdefiniowanym, jako nominalny produkt dezorientuja podmioty gospodarcze i nie dają sygnałów, kiedy czynnik inflacyjny staje się dominujący w polityce pieniężnej. Powrót do konwencjonalnej polityki pieniężnej, gdy nastąpi normalizacja sytuacji gospodarczej, może być utrudniony. Nastąpiło bowiem przerwanie ciągłości celu inflacyjnego i podważona została reputacja banku centralnego, jako strażnika i regulatora poziomu inflacji. Wątły wzrost gospodarczy i deflacja spowodowana załamaniem cen surowców mogły zachęcić banki centralne do przedefiniowania celu polityki pieniężnej13. Ostatecznie ta forma niekonwencjonalnej polityki nie znalazła jednak zwolenników.

\section{Niekonwencjonalność polityki pieniężnej w sensie stosowanych instrumentów}

Niekonwencjonalność polityki pieniężnej pojawiła się po stronie jej instrumentów. Kluczowym czynnikiem było osiągnięcie bariery zerowego poziomu stóp procentowych $\mathrm{w}$ reakcji na recesję połączoną z deflacją. Ten czynnik był decydujący w odniesieniu do konieczności uruchomienia niekonwencjonalnych instrumentów ${ }^{14}$.

Istotny jest różny sposób oddziaływania zerowych stóp procentowych na przedsiębiorstwa i gospodarstwa domowe. Ujemne stopy procentowe możliwe są do wprowadzenia dla komercyjnych podmiotów gospodarczych. Dla nich pieniądz lub, szerzej, aktywa finansowe są jedną $\mathrm{z}$ form przechowywania środków. W przypadku ujemnych stóp zwrotu $\mathrm{z}$ aktywów niefinansowych, jak kapitał produkcyjny, inwesto- 
wanie w kapitał finansowy, mimo ujemnej stopy zwrotu, może okazać się i tak zabiegiem najbardziej opłacalnym, ponieważ stopa ta jest najwyższa spośród powszechnie ujemnych stóp zwrotu ze wszystkich form aktywów.

Powyższego rozumowania nie można powtórzyć w odniesieniu do gospodarstw domowych, które swoje aktywa mogą przechowywać w gotówce. Gotówka ma stopę zwrotu równą zero, zatem jest najbardziej preferowanym aktywem w warunkach ujemnych stóp zwrotu. Powyższy mechanizm można przedstawić, posługując się prostymi, znanymi zależnościami. Niech $R$ oznacza stopę procentową kredytów oferowaną przedsiębiorstwom, a $r$ stopę procentową środków pozyskiwanych przez banki od gospodarstw domowych. Zależność pomiędzy tymi parametrami można zapisać w następującej formie:

7) $R=r+m a+m k+m z$,

gdzie ma oznacza marżę pokrywającą koszty działalności banku, $m k$ marżę kosztu rezerw kredytów nieregularnych, a $m z$ marżę zysku gwarantującą właściwą stopę zwrotu dla akcjonariuszy.

Można przyjąć, że istnieje minimalny, dodatni poziom marż: $m a^{*}, m k^{*}$ i $m z^{*}$, przy jakim banki funkcjonują prawidłowo, równocześnie w warunkach recesji stopa procentowa od kredytów musi spaść do bardzo niskiego poziomu $R^{*}$, poniżej łącznego poziomu marż:

8) $m a^{*}+m k^{*}+m z^{*}>R^{*}$.

W rezultacie przy podanych warunkach stopa procentowa $r$ od środków lokowanych w bankach musiałaby być ujemna:

9) $R^{*}-m a^{*}-m k^{*}-m z^{*}=r<0$.

Warunek powyższy nie może być spełniony dla dowolnego poziomu $R^{*}$ ze względu na możliwość przechowywania środków finansowych w formie gotówki przez gospodarstwa domowe. Ujemne stopy zwrotu od środków deponowanych w bankach przez gospodarstwa domowe mogą mieć stopę niższą od zera pod warunkiem wprowadzenia dodatkowych kosztów związanych z posługiwaniem się gotówką. Margines negatywnych stóp procentowych uzyskiwany dzięki dodatkowym kosztom przechowywania i posługiwania się aktywami finansowymi w formie gotówki jest jednak ograniczony.

\section{Dodatkowe uwarunkowania wymuszające wprowadzenie niekonwencjonalnej polityki pieniężnej przez EBC}

Problem ujemnych stóp procentowych i odpowiedniego przedefiniowania instrumentów polityki pieniężnej w przypadku Europejskiego Banku Centralnego okazał się jeszcze bardziej złożony niż wcześniej zasygnalizowany różny sposób oddziaływania ujemnego oprocentowania na przedsiębiorstwa i gospodarstwa domowe.

Negatywne zjawiska w strefie euro zmuszały do wprowadzenia niekonwencjonalnych metod po to, by przywrócić skuteczność polityce pieniężnej. Kryzys finansów publicznych w wielu krajach strefy euro, niezależnie od jego przyczyn, doprowadził do istotnej dywergencji oprocentowania skarbowych papierów wartościowych poszczególnych krajów. Zmiany rentowności papierów wartościowych podążały za czynnikami lokalnymi, a nie zmianami podstawowych stóp procentowych EBC. W przypadku Irlandii był to efekt pogorszenia się sytuacji w sektorze bankowym, który wymagał dokapitalizowania tego sektora $\mathrm{z}$ publicznych środków. W Hiszpanii był to efekt kryzysu systemu finansowania mieszkalnictwa i konieczność wsparcia tamtejszych kas kredytowych operujących na rynku kredytowym. Włochy, ze względu na wysoki poziom zadłużenia i niskie potencjalne tempo wzrostu gospodarczego, doświadczyły również gwałtownej przeceny skarbowych papierów wartościowych. Ekstremalnym przypadkiem była oczywiście Grecja, gdzie skala kryzysu budżetowego zepchnęła kraj na granicę bankructwa i utraty płynności finansowej. Stopy procentowe od skarbowych papierów wartościowych przestały być podstawą spójnego systemu wyceny ryzyka kredytowego w krajach strefy euro. Inaczej rzecz ujmując: oprocentowanie obligacji w euro przestało wyznaczać krzywą rentowności papierów wartościowych bez ryzyka, ponieważ była ona różna dla różnych krajów strefy. W ten sposób zniknęła możliwość efektywnego oddziaływania polityki pieniężnej na wszystkie kraje za pomocą tylko krótkoterminowej stopy procentowej. 
Problemy finansowe w sektorze publicznym zmuszały do prowadzenia polityki konsolidacji fiskalnej, która oczywiście miała negatywny wpływ na efektywny popyt i w rezultacie na wzrost gospodarczy Stagnacja gospodarcza pogłębiała zapaść finansów publicznych, co ponownie wymuszało obniżenie wydatków publicznych lub zwiększenie obciążeń podatkowych. Powstawało niebezpieczne sprzężenie zwrotne, skutkujące spadkiem aktywności gospodarczej. Coraz gorsze wyniki makroekonomiczne powodowały również wzrost ryzyka kredytowego. Nastąiła segmentacja rynków kredytowych i brak możliwości oddziaływania na nie przy pomocy jednej stopy procentowej.

Niski wzrost gospodarczy, wzrost ryzyka kredytowego, naruszona stabilność publicznego sektora finansowego miały wpływ na wzrost zagrożeń dla europejskiego sektora finansowego. Obowiązujący przed kryzysem system wyceny ryzyka i sposób pokrywania go kapitałem doprowadził do sytuacji, w której europejskie banki pracowały przy zbyt wysokiej dźwigni finansowej. Wzrost ryzyka finansowego zachęcił europejskich regulatorów do zmiany norm ostrożnościowych, których efektem było zwiększenie wymogów kapitałowych. Większość banków europejskich, z uwagi na swoją niską rentowność nie miała łatwej możliwości pozyskania nowego kapitału, w związku z tym zmuszona była do zmniejszenia dźwigni finansowej, co oznaczało drastyczne zahamowanie akcji kredytowej. Proces delewarowania sektora finansowego przebiega w dużym stopniu niezależnie od sytuacji płynnościowej tworzonej przez EBC (por. Cassola, Duree i Holthausen, 2011).

W rezultacie opisanych procesów wspólny obszar walutowy znalazł się w sytuacji podwójnego wyzwania wobec polityki pieniężnej. $\mathrm{Z}$ jednej strony było to oczekiwanie na reaktywację wzrostu gospodarczego za pomocą superluźnej polityki pieniężnej, z drugiej strony EBC miał świadomość nieskuteczności konwencjonalnej polityki pieniężnej w warunkach głębokiej fragmentyzacji wspólnego, europejskiego rynku finansowego ${ }^{15}$.

\section{Cele niekonwencjonalnej polityki pieniężnej EBC}

Pobudzenie wzrostu gospodarczego wymagało obniżenia kredytowych stóp pro- centowych do niskiego poziomu pozwalającego finansować działalność gospodarczą przy bardzo niskiej stopie zysku ${ }^{16}$. Proste obniżenie stopy referencyjnej przez EBC było działaniem niewystarczającym, ponieważ konieczne było równoległe kształtowanie marż bankowych zapewniających stabilne działanie sektora finansowego.

Celem niekonwencjonalnej polityki pieniężnej były działania zmierzające do obniżki wymienionych marż ${ }^{17}$. Marże związane z kosztami funkcjonowania banków nie są bezpośrednio kształtowane przez instrumenty polityki pieniężnej i nadzorczej. Ich poziom jest funkcją zmian technologicznych zachodzących w sektorze bankowym oraz poziomu konkurencyjności wewnątrz tego sektora. Marża związana z ryzykiem kredytowym jest średnią ważoną kosztów ryzyka kredytowego dla poszczególnych klas aktywów. Zależność tę można zapisać w postaci następującej formuły:

10) $m k=\sum_{t=1}^{N} m k_{i} a_{i}$,

gdzie: $m k_{i}$ i $a_{i}$ to odpowiednio wielkość kosztów ryzyka aktywu i jego udział w aktywach całkowitych. Wprowadzenie jako instrumentu polityki pieniężnej skupu aktywów przez EBC (Asset Purchase Programme) umożliwiło obniżenie średniej marży za ryzyko poprzez restrukturyzację portfela aktywów. Proces dostosowawczy zachęcał do sekurytyzacji aktywów, następnie ich sprzedaży i z uzyskanych środków udzielenia nowych kredytów ${ }^{18}$.

Program skupu aktywów miał również znaczenie dla kształtowania pożądanej marży zysku. Ta wielkość jest iloczynem stopy zwrotu na aktywach (Z/A) i dźwigni finansowej $(\mathrm{A} / \mathrm{K})$ :

11) $m z=\frac{Z}{A} \frac{A}{K}$.

Program skupu aktywów pozwalał na podtrzymanie płynności na rynku papierów wartościowych. W przypadku skarbowych papierów wartościowych umożliwiało to ograniczenie zmian cen papierów skarbowych i utrzymanie ich rentowności na w miarę stabilnym poziomie. Banki uzyskały możliwość realizowania zadowalającej stopy zwrotu z inwestycji w skarbowe papiery ${ }^{19}$. Zwiększenie inwestycji $\mathrm{w}$ tym zakresie nie wymagało zwiększenia kapitału, ponieważ niezależnie od kraju emitującego papier skarbowy waga ryzyka była 
przyjmowana na poziomie zero. Marże zysku można było zatem powiększać drogą zwiększania dźwigni finansowej, realizując zakupy skarbowych papierów wartościowych.

Zmniejszenie minimalnych marż wyznaczonych przez ryzyko kredytowe i stope zwrotu na kapitale otwierało możliwość rozbudowy sumy bilansowej poprzez uruchomienie tanich, chociaż nieopartych na ujemnej stopie procentowej, źródeł finansowania. Przeciętna stopa procentowa od środków pozyskiwanych przez banki jest oczywiście średnią stóp środków pochodzących z różnych źródeł. Kluczowym elementem było uruchomienie hurtowego finansowania banków. W warunkach deflacji finansowanie banków za pomoca środków pozyskiwanych od gospodarstw domowych było kosztowne ze względu na próg zerowej stopy procentowej, jak również z powodu kosztów działalności bankowej związanych z pozyskiwaniem finansowania ze strony gospodarstw domowych. Konieczne było zrewitalizowanie rynku międzybankowego. Po pierwsze, należało zmusić banki do aktywniejszej działalności na rynku międzybankowym. EBC osiągnął to, wprowadzając ujemną stopę depozytową (Negative Deposit Rate). Po drugie, fluktuacje na rynku międzybankowym wymagały zabezpieczenia ryzyka płynności w średnim okresie dla banków refinansujących się z rynku międzybankowego. Temu celowi służył program TL-TRO (Targeted Long-Term Refinancing Operations). Łączne wprowadzenie tych dwóch instrumentów zmniejszyło koszty finansowania sektora bankowego i przyczyniło się do spadku stóp procentowych od kredytów ${ }^{20}$.

\section{Znaczenie programu skupu obligacji skarbowych}

Program skupu aktywów, w szczególności skarbowych papierów wartościowych, miał wielorakie znaczenie. Po pierwsze, stał się on instrumentem kształtowania krzywej dochodowości w sytuacji, gdy zmiany krótkoterminowej stopy procentowej nie wpływały automatycznie na odpowiednie jej przesunięcie. W ten sposób bank centralny uzyskał instrument regulowania kosztu płynności w różnych okresach. Po drugie, skup obligacji ograniczył i ustabilizował stopy procentowe od skarbowych papierów wartościowych. Miało to znaczenie dla warunków rolowania długu publicznego i kosztów jego obsługi, a także pośrednio wpływało na koszty kredytu dla przedsiębiorstw.

Tradycyjnie, obligacje $\mathrm{w}$ danym kraju wyznaczają minimalną stopę procentową od aktywów, ponieważ przyjmuje się je jako aktywo o praktycznie zerowym ryzyku kredytowym. Rynki finansowe zakładaja, że kraj nie zbankrutuje we własnej walucie. W przypadku zagrożenia płynności sektora publicznego uruchomiona zostanie interwencja banku centralnego, który ma nieograniczoną możliwość kreacji pieniądza stanowiącego prawny środek płatniczy. $\mathrm{W}$ związku z powyższym oprocentowanie kredytów komercyjnych musi być wyższe w stosunku do stopy procentowej obligacji o marżę odzwierciedlającą poziom ryzyka kredytowego danego przedsiębiorstwa (firma może zbankrutować).

W początkowym okresie funkcjonowania strefy euro, w percepcji rynków finansowych, dominował pogląd, że mimo deklarowanego zakazu ratowania finansów publicznych poszczególnych krajów Unii, bank centralny wspólnego obszaru walutowego znajdzie formułę dla realizacji funkcji pożyczkodawcy ostatniej instancji, tak jak było to $\mathrm{w}$ przypadku narodowych banków centralnych ${ }^{21}$. W związku z tym żaden kraj ze strefy euro nie powinien stracić dostępu do rynków finansowych. Przyjmowano, że wprowadzony na szczeblu Unii Europejskiej system kontroli deficytu i długu publicznego nie dopuści do gwałtownego wzrostu deficytu i nadmiernego zadłużenia krajów-członków strefy. Uznawano również, że system rozliczeń wewnątrz strefy pozwala narodowym bankom centralnym na pozyskiwanie przejściowo płynności z EBC pod zastaw skarbowych papierów wartościowych danego kraju. Płynność wstrzykiwana za pośrednictwem narodowych banków centralnych pozwalała podtrzymać również wewnętrzny system rozliczeń międzybankowych (tzw. TARGET2), w ramach którego możliwe było sfinansowanie ujemnych sald sektora bankowego poszczególnych krajów. W rezultacie rynki finansowe w niewielkim stopniu różnicowały rentowność skarbowych papierów wartościowych krajów strefy euro. W szczytowym okresie prosperity krajów strefy euro różnica rentowności skarbowych papierów krajów strefy euro do niemieckich „,bundów” wynosiła kilkanaście punktów bazowych. 
Kryzys finansowy zweryfikował ten pogląd - wzrost deficytu sektora publicznego spowodował istotny wzrost oprocentowania skarbowych papierów wartościowych, a w przypadku Grecji praktycznie odcięcie od finansowania przez sektor bankowy. Okazało się, że Unia Europejska nie ma wypracowanych instrumentów reakcji na kryzys fiskalny i praktycznie, w przypadku Grecji, była zdana na uruchomienie programu stabilizacyjnego Międzynarodowego Funduszu Walutowego.

Gwałtowny proces dywergencji rentowności skarbowych papierów wartościowych państw strefy euro spowodował procesy podkopujące istotę wspólnej polityki pieniężnej i wspólnego rynku finansowego strefy euro. Stopy procentowe dla kredytobiorców o tym samym profilu ryzyka okazały się różne w zależności od kraju, w którym były udzielane. Efekt zróżnicowania był spowodowany istotną różnicą w rentowności skarbowych papierów wartościowych poszczególnych krajów. Inaczej mówiąc: zniknęła jednolita krzywa dochodowości dla strefy euro wyznaczona w oparciu o rynek skarbowych obligacji denominowanych w euro.

Interwencja na rynku obligacji miała przywrócić spójność rynku finansowego strefy euro. Oprócz niekonwencjonalnego instrumentu, jakim był skup przez EBC obligacji skarbowych o różnym terminie zapadalności, państwa strefy euro odpowiednio dostosowały strukturę finansowania długu publicznego, posługując się w większej ilości krótkoterminowymi papierami wartościowymi. W rezultacie podaż długoterminowych papierów skarbowych została w sposób naturalny ograniczona i tym samym zwiększała skuteczność interwencji EBC na rynku finansowym.

\section{Skutki stosowania niekonwencjonalnych instrumentów polityki pieniężnej}

Spójne zastosowanie trzech niekonwencjonalnych instrumentów: ujemnej stopy depozytowej, programu długoterminowego refinansowania banków oraz programu zakupu aktywów w znacznej mierze przywróciło skuteczność polityce pieniężnej22.

Po pierwsze, mimo progu ujemnych stóp procentowych udało się „zepchnąć” stopy procentowe od kredytów do poziomu gwarantującego stopniowe pobudzenie akcji kredytowej, odpowiednio wpływając na wcześniej opisany system marż. Od momentu deklaracji przez EBC pakietu niekonwencjonalnych posunięć (połowa 2014 roku) w ciągu dwóch lat spadkowi kosztów refinansowania banków o 20 punktów bazowych towarzyszył średni spadek stóp procentowych kredytów o ponad 110 punktów. Należy przy tym zaznaczyć, że spadek stóp procentowych kredytów byl silniejszy dla Hiszpanii i Włoch niż dla Niemiec.

Po drugie, zapewniono stabilizację stóp procentowych obligacji krajów najbardziej dotkniętych kryzysem finansowym (z wyjątkiem Grecji). W ten sposób ustabilizowano refinansowanie sektora publicznego i ograniczono koszty obsługi długu publicznego, pozwalając na stopniową stabilizację fiskalną bez znacznych strat w zakresie tempa wzrostu gospodarczego.

Po trzecie, niekonwencjonalne instrumenty polityki pieniężnej pozwoliły na przywrócenie procesu konwergencji stóp procentowych od kredytów zarówno dla przedsiębiorstw, jak i gospodarstw domowych. Postęp w tym zakresie był jednak zróżnicowany i zależał nie tylko od sytuacji finansów publicznych (zróżnicowania stóp procentowych obligacji skarbowych), ale również od sytuacji w narodowych sektorach bankowych. Mimo istnienia bariery zerowej stopy procentowej, koszt refinansowania banków był różny i zależał od czynników lokalnych. Polityka marż, rzutująca na ostateczny koszt kredytów, była związana z sytuacją finansową poszczególnych banków. Istotne znaczenie miała również struktura portfela; znaczny udział w nim nowo udzielanych kredytów podnosił koszt finansowania ze względu na podwyższone ryzyko.

Dalszy postęp w procesie konwergencji stóp procentowych jest już uzależniony nie od rozbudowania niekonwencjonalnych instrumentów polityki pieniężnej, ale procesów przywracania spójności systemowi finansowania. Powodzenie w zakresie budowy kolejnych elementów Unii Bankowej jest warunkiem osiąnnięcia zadowalającego poziomu spójności europejskiego rynku finansowego.

Ograniczenie niekonwencjonalności polityki pieniężnej tylko do instrumentów i zaniechanie działań zmierzających do redefinicji celu polityki pieniężnej okazało się słuszne. Nie nastąpiło trwałe odkotwi- 
czenie oczekiwań inflacyjnych, ani silna dywergencja procesów inflacyjnych w różnych krajach strefy euro. Zastosowane niekonwencjonalne instrumenty pozwalają na elastyczne kształtowanie przyszłej strategii ich stopniowego wycofania.

\section{Przypisy}

1 Autor dziękuje za cenne uwagi p. prof. Tomaszowi Łyziakowi.

2 Uwarunkowania prowadzenia polityki pieniężnej można znaleźć w pracy: Friedman (1968).

3 Omówienie uwarunkowań w pracy: Sachs (1996).

4 Przegląd stosowanych strategii polityki pieniężnej w pracy: Bernanke i Mishkin (1992).

5 W literaturze ten czynnik stał się kryterium podziału na „ścisłą” i „elastyczną" strategię polityki pieniężnej; Svensson (2002).

6 Zakładając niezmienione oczekiwania co do przyszłej krótkoterminowej stopy procentowej.

7 Celu inflacyjnego rozumianego jako poziom albo przedział ściśle określonego miernika inflacji.

8 Dokładne omówienie uwarunkowań polityki Fed w pracy: Poole (2006).

9 Ocenę skuteczności zawiera praca: McKay, Nakamura i Steinsson (2015).

10 Idea opisana w pracy: Hall i Mankiw (1994).

11 Problem rozumienia elastyczności pośrednio ujęty w pracy Frankela (2013).

12 Wpływ różnych celów na mechanizm transmisji omawia praca Lam (2003).

13 Omówienie doświadczeń z kryzysu finansowego w pracy Mishkin (2001).

14 Sposoby dostosowania polityki pieniężnej w tych warunkach w pracy Woodford (2012).

15 Dostosowania polityki pieniężnej omawia praca: Houben (2000)

16 Skutki zmniejszenia marż w tych warunkach omawia praca: Baumeister i Benati (2013).

17 Zadania dla polityki pieniężnej w pokryzysowym okresie omawia Goodhart (2010).

18 Ocenę skuteczności program zawiera praca: Eser i Schwaab (2013).

19 Ocena niekonwencjonalnej polityki w tym zakresie w pracy: Szczerbowicz (2012).

20 Skutki skupu aktywów omawia praca: Weale i Wieladek (2016).

21 Szukanie formuły działania banku centralnego w pracy: Issing (2011).

22 W rezultacie przyjęto formułę elastycznego celu inflacyjnego, np. Svensson (2009).

\section{Bibliografia}

Baumeister, C. i Benati, L. (2013). Unconventional monetary policy and the great recession: estimating the macroeconomic effects of a spread compression at the zero lower bound. International Journal of Central Banking, 9, 165-212.

Bernanke, B. i Mishkin, F.S. (1992). Central bank behavior and the strategy of monetary policy: observations from six industrialized countries. W: O. Blanchard i S. Fischer (red), NBER Macroeconomics Annual, 7.

Blinder, A. (2001). Central Bank in Theory and Practice. MIT Press.

Cassola, N., Durré A. i Holthausen C. (2011). Monetary Policy Operations: experiences during the crisis and lessons learnt. Proceedings of the Sixth ECB Central Banking Conference, Approaches to monetary policy revisited - lessons from the crisis, 280-321.

Eser, F. i Schwaab B. (2013). Assessing asset purchases within the ECB's securities markets programme. ECB Working Paper, 1587.

Frankel, J. (2013). Nominal GDP targets, without losing the inflation anchor. W: R. Baldwin i L. Reichlin (red), Is Inflation Targeting Dead? Central Banking After the Crisis. Centre for Economic Policy Research.

Friedman, M. (1968). A theoretical framework for monetary analysis. The Journal of Political Economy, 78(2), 193-238.

Goodhart, C. (2010). The changing role of central banks. Bank of International Settlements Working Paper, 326.

Hall, R.E. i Mankiw, N.G. (1994). Nominal income targeting. W: N.G. Mankiw (red.), Monetary Policy, The University of Chicago Press.

Houben, A. (2000). The Evolution of Monetary Policy Strategies in Europe. Kluwer Academic Publishers.

Issing, O. (2011). Lessons for monetary policy: What should the consensus be? IMF Working Paper, 97.

Jensen, H. (2002). Targeting nominal income growth or inflation? The American Economic Review, 92(4), 928-956.

Lam, J.-P. (2003). Alternative targeting regimes, transmission lags, and the exchange rate channel. Bank of Canada Working Paper, 39.

McKay, A.A., Nakamura, E. i Steinsson, J. (2015). The power of forward guidance revisited. NBER Working Paper, 20882.

Mishkin, F. (2011). Monetary policy strategy: lessons from crisis. NBER Working Paper, 16755.

Poole, W. (2006). The Fed's monetary policy rule. Review of Federal Reserve Bank of St. Louis, 88(1), $1-11$.

Sachs, J.D. (1996). Economic transition and the exchange-rate regime. The American Economic Review, 86(2), 147-152. 
Svensson. L.E.O. (2002). Monetary Policy and Real Stabilization. Federal Reserve Bank of Kansas City - Rethinking Stabilization Policy - Symposium - Jackson Hole, 261-312.

Svensson, L.E.O. (2009). Flexible inflation targeting - lessons from the financial crisis. BIS Review, 112/2009.

Szczerbowicz, U. (2012). The ECB unconventiona monetary policies: have they lowered market borrowing costs for banks and governments? Working Paper CEPII Research Center, 2012/36.
Tobin, J. (1983). Monetary policy: rules, targets, and shocks. Journal of Money, Credit and Banking, 15(4), 506-518.

Weale, M. i Wieladek T. (2016). What are the macroeconomic effects of asset purchases? Journal of Monetary Economics, 79, 81-93.

Woodford, M. (2012). Methods of policy accommodation at the interest-rate lower bound, Federal Reserve Bank of Kansas City, Proceedings - Economic Policy Symposium - Jackson Hole, 185-288. 